\title{
Review: Nutritional ecology of heavy metals
}

\author{
M. Hejna ${ }^{1 \dagger}$, D. Gottardo ${ }^{1}$, A. Baldi ${ }^{1}$, V. Dell'Orto ${ }^{1}$, F. Cheli ${ }^{1}$, M. Zaninelli ${ }^{2}$ and L. Rossi ${ }^{1}$ \\ ${ }^{1}$ Department of Health, Animal Science and Food Safety, The University of Milan, Via Trentacoste 2, 20134 Milan, Italy; ${ }^{2}$ Università telematica San Raffaele Roma, \\ Via di Val Cannuta 247, 00166 Rome, Italy
}

(Received 20 June 2017; Accepted 23 November 2017; First published online 8 January 2018)

\begin{abstract}
The aim of this review is to focus the attention on the nutrition ecology of the heavy metals and on the major criticisms related to the heavy metals content in animal feeds, manure, soil and animal-origin products. Heavy metals are metallic elements that have a high density that have progressively accumulated in the food chain with negative effects for human health. Some metals are essential ( $\mathrm{Fe}, \mathrm{I}, \mathrm{Co}, \mathrm{Zn}, \mathrm{Cu}, \mathrm{Mn}, \mathrm{Mo}, \mathrm{Se}$ ) to maintain various physiological functions and are usually added as nutritional additives in animal feed. Other metals ( $\mathrm{As}, \mathrm{Cd}, \mathrm{F}, \mathrm{Pb}, \mathrm{Hg}$ ) have no established biological functions and are considered as contaminants/ undesirable substances. The European Union adopted several measures in order to control their presence in the environment, as a result of human activities such as: farming, industry or food processing and storage contamination. The control of the animal input could be an effective strategy to reduce human health risks related to the consumption of animal-origin products and the environmental pollution by manure. Different management of raw materials and feed, animal species as well as different legal limits can influence the spread of heavy metals. To set up effective strategies against heavy metals the complex interrelationships in rural processes, the widely variability of farming practices, the soil and climatic conditions must be considered. Innovative and sustainable approaches have discussed for the heavy metal nutrition ecology to control the environmental pollution from livestockrelated activities.
\end{abstract}

Keywords: heavy metals, livestock, nutrition, manures, environmental impact

\section{Implications}

This study focuses on the role of animal production and on the main challenges related to the content of essential and non-essential heavy metals in animal feed and manure as a basis for developing effective approaches to the reduction of heavy metal pollution from livestock.

\section{Introduction}

Metals are natural constituents of the earth's crust and through natural erosion due to water and wind, they are naturally spread into the environment as powders or leached into rivers. However, these natural processes emit fewer metals into the environment than anthropological activities. The spread of high amounts of these elements in the environment leads to their propagation in the food chain. Heavy metals (e.g. $\mathrm{Fe}, \mathrm{Co}, \mathrm{Cu}$, $\mathrm{Mn}, \mathrm{Mo}, \mathrm{Se}, \mathrm{Zn}, \mathrm{Cr}$ and $\mathrm{Cd}, \mathrm{Hg}, \mathrm{Pb}, \mathrm{As}$ ) are metallic elements that have a high density compared with water and are present in various matrices in traces. Their heaviness and toxicity are interrelated, as heavy metals are able to induce toxicity at low doses (Bhargava et al., 2012; Govind and Madhuri, 2014; Dai et al., 2016; Giromini et al., 2016).

\footnotetext{
${ }^{\dagger}$ E-mail: monika.hejna@unimi.it
}

Some metals are essential to maintain various biochemical and physiological functions in humans, animals and plants. The nutritional requirements of these trace elements, such as cobalt $(\mathrm{Co})$, copper $(\mathrm{Cu})$, chromium $(\mathrm{Cr})$, iron $(\mathrm{Fe})$, manganese $(\mathrm{Mn})$, molybdenum (Mo), selenium ( $\mathrm{Se}$ ) and zinc ( $\mathrm{Zn}$ ) are generally low and they are called microelements. They are present in various matrices, although with a different bioavailability, in trace concentrations (ppb or ppm) (Hambidge, 2003). Essential trace elements are usually added as nutritional additives in animal feed to promote health, and to optimize production (European Union (EU) Reg. 1881/2006). However, excessive exposure with higher concentration of these elements has been linked with cellular or systemic disorders and could represent a source of pollution (Rossi et al., 2014b).

Other metals (e.g. As, Cd, Pb, Hg) have no established biological functions and are considered as contaminants and undesirable substances in animal feed (Reg. 2002/32/EC). Moreover, $\mathrm{As}, \mathrm{Cd}, \mathrm{Cr}, \mathrm{Pb}$ and $\mathrm{Hg}$ which are a prior hazard to public health, present a high toxicity because they can induce organ damage, even at lower exposure levels (Table 1).

The toxicity of heavy metals, whether essential or not, depends on several factors including the dose, route of exposure, and chemical species, as well as the age, gender, genetics and nutritional status of the exposed individuals 
Table 1 Heavy metals in nutrition

\begin{tabular}{ll}
\hline \hline \multicolumn{1}{c}{ Heavy metals } \\
\hline $\begin{array}{l}\text { Essential elements } \\
\text { (authorized in animal nutrition*) }\end{array}$ & $\begin{array}{c}\text { Non-essential elements } \\
\text { (undesirable**) }\end{array}$ \\
\hline $\mathrm{Co}$ (cobalt) & As (arsenic) \\
$\mathrm{Cr}$ (chromium) & $\mathrm{Cd}$ (cadmium) \\
$\mathrm{Cu}$ (cooper) & $\mathrm{Hg}$ (mercury) \\
$\mathrm{Fe}$ (iron) & $\mathrm{Pb}$ (lead) \\
$\mathrm{Mn}$ (manganese) & \\
$\mathrm{Mo}$ (molybdenum) & \\
$\mathrm{Ni}$ (nickel) & \\
$\mathrm{Se}$ (selenium) & \\
$\mathrm{Zn}$ (zinc) & \\
\hline \hline
\end{tabular}

According to Theron et al. (2012) and Govind and Madhuri (2014).

${ }^{*}$ Additives authorized in animal nutrition according to EC No 1831/2003.

**Undesirable elements according to 2002/32/EC.

(Tchounwou et al., 2012). They have different effects in relation to the dose and the time of consumption: acute poisoning for high doses in a short period and chronic poisoning or bioaccumulation for reduced exposure over a long period.

In the long term, the accumulation of heavy metals in soil can lead to a deterioration of agricultural land, eutrophication and the absorption of toxic substances. This could have longterm implications for the quality of agricultural soils, including phytotoxicity at high concentrations, the maintenance of soil microbial processes, and the transfer of zootoxic elements to the human diet due to an increased crop uptake or soil ingestion by grazing livestock (Nicholson et al., 2003).

In the last decade the EU has been promoting the reduction of nutrient and heavy metal pollution of water and soil given that such pollutants are the major cause of eutrophication. The contamination of food and feed with heavy metals has become a serious problem in intensive agriculture.

Moreover, with regard to farming livestock, a global nutritional ecology strategy is needed in order to guarantee both the health status of humans and animals and sustainable productions. The ecology of nutrition is a multidisciplinary approach, mainly focusing on living organisms, the environment and the nutritional basis of the cooperation between organisms (function, mechanism, development) and the environment (biotic and abiotic) (Raubenheimer et al., 2009). Considering the great variety of heavy metals in the environment, it is impossible to avoid the presence of heavy metals in the food chain, and in the environment.

This study focuses on the role of animal production and on the main challenges related to the content of essential and non-essential heavy metals in animal feed and manure as a basis for developing effective approaches to the reduction of heavy metal pollution from livestock.

\section{Legislative context}

The EU authorities have thus adopted various measures to control heavy metals presence in the environment, as a result of human activities such as farming, industry, and food processing and storage contamination. Therefore, reducing heavy metal inputs to the environment and the absolute decoupling are the main focus of EU environmental protection policies given that promote continued economic growth with a reduction in environmental impacts (Jarup, 2003). The EU has established comprehensive regulations on the maximum authorized admissible concentrations of essential ( $\mathrm{Fe}, \mathrm{I}, \mathrm{Co}, \mathrm{Cu}, \mathrm{Mn}, \mathrm{Zn}, \mathrm{Mo}, \mathrm{Se}$ ) and undesirable substances (As, $\mathrm{Cd}, \mathrm{F}, \mathrm{Pb}, \mathrm{Hg}$ ) (Table 2). Moreover, different maximum inclusion levels of essential trace elements in additives for use in animal nutrition have been set (Table 3). Main aim of those regulations (EC Reg. No 1831/2003; Dir. 2002/32/EC) is to protect feed and food safety, and ultimately human health, and reducing environmental pollution (Fink-Gremmels, 2012).

Considering the great variety of heavy metals in the environment and their concentration within different feed production chains, it is impossible to achieve lower levels of contamination than the detection limit for all elements in all products. It is therefore necessary to work at different levels (Aragay et al., 2011). The EU is aware of all these problems and several laws have thus been enacted in order to control all heavy metal pollution, reduce the risk of human exposure in the food chain as well as setting up detection methods to control these contaminants in the food chain.

\section{Heavy metals and human health}

Humans and animals can be exposed to heavy metals and trace elements through different routes: the inhalation of air pollutants, consumption of contaminated drinking water, exposure to contaminated soils or industrial waste, and the ingestion of contaminated food, such as vegetables, grains, fruits, fish and shellfish and meat (Duruibe et al., 2007). The main source of exposure differs according to the elements. For example, $\mathrm{Cd}$ is present at low levels in most foods, such as whole grain cereals, fruit, root vegetables, meat and fish. The highest levels of $\mathrm{Cd}$ metals are found in the offal (kidney and liver) of mammals and in mussels, oysters and scallops. Heavy metals cause serious impacts on human and animal health including reduced growth and development, cancer, organ damage, nervous system damage, and in extreme cases, death (Table 4) (Thirulogachandar et al., 2014). The International Agency for Research on Cancer considered some heavy metals as carcinogenic to humans, based on evidence on human studies. Some metals are particularly toxic to the sensitive, rapidly developing systems of fetuses, infants and young children. $\mathrm{Pb}$ and $\mathrm{Hg}$ in particular, can easily cross the placenta and damage the fetal brain (Food Safety Authority of Ireland, 2009).

Childhood exposure to some metals can result in learning difficulties, memory impairment, damage to the nervous system, and behavioral problems such as aggressiveness and hyperactivity. At higher doses, heavy metals can cause irreversible brain damage (Jaishankar et al., 2014). It is also very important to consider that children receive higher doses of metals from food than adults, as they consume more food in relation to their BW (Thirulogachandar et al., 2014). The probability that a population will be exposed and harmed could 
Table 2 Main European Union (EU) regulations concerning essential and undesirable substances contamination

Regulations

Full title and main content

EUR-lex link

Directive 2002/32/EC

Directive of the European Parliament and of the council of 7 May 2002 on undesirable substances in animal feed

Regulation (EC) N 1831/2003 Establishes a procedure for authorizing the placing on the market and use of feed additives and to lay down rules for the supervision and labelling of feed additives and premixtures

Regulation (EC) N 1881/2006 Represents the main guidelines concerning contaminants in foodstuffs; it sets maximum levels of mycotoxins, metals

$(\mathrm{Pb}, \mathrm{Cd}, \mathrm{Hg}$ and $\mathrm{Sn})$, dioxins and Polychlorinated biphenyls (PCBs) in different food sources

Regulation (EC) N 776/2006 Defines the community reference laboratories responsible for the official controls performed to ensure the verification of compliance with feed and food law, animal health and animal welfare rules

Regulation (EC) N 1754/2006 Lays down detailed rules for the granting of Community financial assistance for the organization of workshops

Regulation (EC) N $\mathrm{N}^{\circ} 333 / 2007$ Specifies the sampling methods and the methods of analysis for the official control of the levels of lead, cadmium, mercury, inorganic tin, 3-monochloropropane-1,2-diol (3-MCPD) and benzo(a)pyrene in foodstuffs. It is divided into four parts (A, B, C and D) that deal with the 'definitions', 'sampling methods', 'sample preparation and analysis' and lastly 'reporting and interpretation of results, respectively

Regulation (EC) No 629/2008 Amends the previous Regulation (EC) No 1881/2006 that sets maximum levels for certain contaminants in foodstuffs. It modifies the maximum levels for lead, cadmium and mercury. Regarding lead, this regulation adds the category of 'food supplements' and specifies the species of cultivated mushrooms. For cadmium and mercury, it makes the list of fish species easier to consult

Regulation (EC) N 767/2009 Regulation of the European parliament and of the council of 13 July 2009 on the use of feed, amending European Parliament and Council Regulation (EC) No 1831/2003 amending the conditions for authorization of a number of additives in feedstuffs belonging to the group of trace elements

Regulation (EU) No 836/2011 Amends Regulation (EC) No 333/2007 and changes the title to: 'laying down the methods of sampling and analysis for the official control of the levels of lead, cadmium, mercury, inorganic tin, 3-monochloropropane-1,2-diol (3-MCPD) and benzo(a)pyrene in foodstuffs'

Regulation (EU) N 1275/2013 Amends Annex I to Directive 2002/32/EC of the European Parliament and of the Council as regards maximum levels for arsenic, cadmium, lead, nitrites, volatile mustard oil and harmful botanical impurities, and reduces the levels of arsenic and lead and modifies the feed materials concerning volatile mustard oil levels

Regulation (EU) N 488/2014 Amends Regulation (EC) No 1881/2006 as regards maximum levels of cadmium in foodstuffs.

It now includes different categories such as 'Infant formulae,' 'Processed cereal-based foods and baby foods for infants and young children' and 'Specific cocoa and chocolate products'

Regulation (EU) N 1005/2015 Amends the Regulation (EC) No 1881/2006 modifying the maximum levels of lead in certain foodstuffs such as foods for special medical purposes intended specifically for infants and young children, and also beverages

Regulation (EU) No 1006/2015 Amends the previous Regulation (EC) No 1881/2006 as regards maximum levels of inorganic arsenic and introduces a subsection on arsenic levels in rice and rice products

Regulation (EU) N ${ }^{\circ}$ 582/2016 Amends Regulation (EC) No 333/2007. The main differences concern the title and Table 5 regarding the 'Performance criteria for methods of analysis for lead, cadmium, mercury, inorganic tin and inorganic arsenic' where the maximum levels of cadmium, mercury, inorganic arsenic and lead are added http://data.europa.eu/eli/dir/ 2002/32/oj

tttp://data.europa.eu/eli/dir/ 2003/1831/oj

http://data.europa.eu/eli/reg/ 2006/1881/oj

http://data.europa.eu/eli/reg/ 2006/776/oj

http://data.europa.eu/eli/reg/ 2006/1754/oj

http://data.europa.eu/eli/reg/ 2007/333/oj

http://data.europa.eu/eli/reg/ 2008/629/oj

http://data.europa.eu/eli/reg/ 2009/767/oj

http://data.europa.eu/eli/reg/ 2011/836/oj

http://data.europa.eu/eli/reg/ 2013/1275/oj

http://data.europa.eu/eli/ reg_impl/2014/448/oj

http://data.europa.eu/eli/reg/ 2015/1005/oj

http://data.europa.eu/eli/reg/ 2015/1006/oj

http://data.europa.eu/eli/reg/ 2016/582/oj 
Review: Nutritional ecology of heavy metals

Table 3 Maximum levels of essential trace elements and undesirable substances in feeds according to different European Union legislation (EC N ${ }^{\circ}$ 1831/2003; 2002/32/EC) and nutritional requirement for different species

\begin{tabular}{|c|c|c|c|c|}
\hline Elements & $\mathrm{EEC} \mathrm{N}^{\circ}$ & Sources & Nutritional requirements & $\begin{array}{l}\text { Maximum level } \mathrm{mg} / \mathrm{kg} \text { dry } \\
\text { matter of complete diet }\end{array}$ \\
\hline \multicolumn{5}{|l|}{ Essential trace elements } \\
\hline \multirow[t]{8}{*}{ Iron (Fe) } & \multirow[t]{8}{*}{ E1 } & Carbonate ferrous & Swine: & \multirow{4}{*}{$\begin{array}{l}\text { Swine: } \\
\text { Weaning: } 250 \mathrm{mg} / \mathrm{day} \\
\text { Other pigs: } 750 \mathrm{mg} / \mathrm{kg}\end{array}$} \\
\hline & & Ferrous chlorides & Pigs 5-7 kg: 100 ppm & \\
\hline & & Ferrous fumarate & Gestation: 80 ppm & \\
\hline & & Iron oxide & Lactation: 80 ppm & \\
\hline & & Ferrous sulfates & Cattle: & \multirow{4}{*}{$\begin{array}{l}\text { Cattle: } \\
750 \mathrm{mg} / \mathrm{kg}\end{array}$} \\
\hline & & Ferrous hydrate chelates & Growing: $50 \mathrm{mg} / \mathrm{kg}$ & \\
\hline & & & Gestation: $50 \mathrm{mg} / \mathrm{kg}$ & \\
\hline & & & Early lactation: $50 \mathrm{mg} / \mathrm{kg}$ & \\
\hline \multirow[t]{8}{*}{ lodine (I) } & \multirow[t]{8}{*}{ E2 } & Calcium iodide hexahydrate & Swine: & \multirow{4}{*}{$\begin{array}{l}\text { Swine: } \\
\text { Pigs: } 10 \mathrm{mg} / \mathrm{kg}\end{array}$} \\
\hline & & Anhydrous calcium iodate & Pigs $5-7 \mathrm{kg:} 0.14$ ppm & \\
\hline & & Sodium iodide & Gestation: 0.14 ppm & \\
\hline & & Potassium iodide & Lactation: 0.14 ppm & \\
\hline & & & Cattle: & \multirow{4}{*}{$\begin{array}{l}\text { Cattle: } \\
\text { Dairy cows: } 5 \mathrm{mg} / \mathrm{kg} \\
\text { Other categories: } 10 \mathrm{mg} / \mathrm{kg}\end{array}$} \\
\hline & & & Growing: 0.5 mg/kg & \\
\hline & & & Gestation: $0.5 \mathrm{mg} / \mathrm{kg}$ & \\
\hline & & & Early lactation: $0.5 \mathrm{mg} / \mathrm{kg}$ & \\
\hline \multirow[t]{6}{*}{ Cobalt (Co) } & \multirow[t]{6}{*}{ E3 } & Acetate tetrahydrate cobalt & & \multirow[t]{2}{*}{ Pigs: 2 mg/kg } \\
\hline & & Carbonate monohydrate cobalt & & \\
\hline & & Cobalt chloride hexahydrate & Cattle: & \multirow{4}{*}{$\begin{array}{l}\text { Bovine: maximum } 1 \mathrm{mg} / \mathrm{kg} \\
(0.3 \mathrm{mg} / \mathrm{kg} \text { recommended })\end{array}$} \\
\hline & & Cobalt sulphates & Growing: 0.1 mg/kg & \\
\hline & & & Gestation: $0.1 \mathrm{mg} / \mathrm{kg}$ & \\
\hline & & & Early lactation: $0.1 \mathrm{mg} / \mathrm{kg}$ & \\
\hline \multirow[t]{9}{*}{ Copper (Cu) } & \multirow[t]{9}{*}{ E4 } & Copper acetate monohydrate & Swine: & \multirow{5}{*}{$\begin{array}{l}\text { Swine: } \\
\text { Piglets up to } 12 \text { weeks: } 170 \mathrm{mg} / \mathrm{kg} \\
\text { Other pigs: } 25 \mathrm{mg} / \mathrm{kg}\end{array}$} \\
\hline & & Carbonate monohydrate copper & Pigs 5-7 kg: 6 ppm & \\
\hline & & Cupric chloride dihydrate & Gestation: 10 ppm & \\
\hline & & Copper methionate & Lactation: 20 ppm & \\
\hline & & Cupric oxide & & \\
\hline & & Cupric sulphates & Cattle: & \multirow{4}{*}{$\begin{array}{l}\text { Cattle: } \\
\text { Milking cows: } 15 \mathrm{mg} / \mathrm{kg} \\
\text { Other bovine: } 35 \mathrm{mg} / \mathrm{kg}\end{array}$} \\
\hline & & Copper chelates & Growing: 10 mg/kg & \\
\hline & & & Gestation: 10 mg/kg & \\
\hline & & & Early lactation: $10 \mathrm{mg} / \mathrm{kg}$ & \\
\hline \multirow[t]{8}{*}{ Manganese (Mn) } & \multirow[t]{8}{*}{ E5 } & Manganous carbonate & Swine: & \multirow[t]{8}{*}{ All species: $150 \mathrm{mg} / \mathrm{kg}$} \\
\hline & & Manganous chloride tetrahydrate & Pigs $5-7 \mathrm{~kg}: 4 \mathrm{ppm}$ & \\
\hline & & Manganese oxide & Gestation: 25 ppm & \\
\hline & & Manganous sulphates & Lactation: 25 ppm & \\
\hline & & Manganese hydrates & Cattle: & \\
\hline & & Manganese chelates & Growing: 20 mg/kg & \\
\hline & & & Gestation: $40 \mathrm{mg} / \mathrm{kg}$ & \\
\hline & & & Early lactation: 40 mg/kg & \\
\hline \multirow[t]{8}{*}{ Zinc (Zn) } & E6 & Zinc lactate hydrates & Swine: & Pigs: $150 \mathrm{mg} / \mathrm{kg}$ \\
\hline & & Zinc carbonate & Pigs $5-7 \mathrm{~kg}: 100 \mathrm{ppm}$ & \\
\hline & & Zinc chloride monohydrate & Gestation: 100 ppm & \\
\hline & & Zinc oxide & Lactation: 100 ppm & \\
\hline & & Zinc sulfates & Cattle: & Cattle: $100 \mathrm{mg} / \mathrm{kg}$ \\
\hline & & Zinc chelates & Growing: 30 mg/kg & \\
\hline & & & Gestation: 30 mg/kg & \\
\hline & & & Early lactation: 30 mg/kg & \\
\hline Molybdenum (Mo) & E7 & Ammonium molybdate & & All species: $2.5 \mathrm{mg} / \mathrm{kg}$ \\
\hline & & Sodium molybdate & & \\
\hline
\end{tabular}


Hejna, Gottardo, Baldi, Dell'Orto, Cheli, Zaninelli and Rossi

Table 3: (Continued)

\begin{tabular}{|c|c|c|c|c|}
\hline Elements & EEC N ${ }^{\circ}$ & Sources & Nutritional requirements & $\begin{array}{l}\text { Maximum level mg/kg dry } \\
\text { matter of complete diet }\end{array}$ \\
\hline \multirow[t]{2}{*}{ Selenium (Se) } & E8 & $\begin{array}{l}\text { Sodium selenite } \\
\text { Sodium selenate }\end{array}$ & $\begin{array}{l}\text { Pigs } 5-7 \mathrm{~kg}: 0.3 \mathrm{ppm} \\
\text { Gestation: } 0.15 \mathrm{ppm} \\
\text { Lactation: } 0.15 \mathrm{ppm}\end{array}$ & All species: $0.5 \mathrm{mg} / \mathrm{kg}$ \\
\hline & & $\begin{array}{l}\text { Produced by Saccharomyces } \\
\text { cerevisiae strains }\end{array}$ & $\begin{array}{l}\text { Cattle: } \\
\text { Growing: } 0.1 \mathrm{mg} / \mathrm{kg} \\
\text { Gestation: } 0.1 \mathrm{mg} / \mathrm{kg} \\
\text { Early lactation: } 0.1 \mathrm{mg} / \mathrm{kg}\end{array}$ & \\
\hline \multicolumn{5}{|c|}{ Undesirable substances (and non-essential trace elements) } \\
\hline Arsenic (As) & & Complete feed & - & $2 \mathrm{mg} / \mathrm{kg}$ \\
\hline Cadmium (Cd) & & Complete feed & - & $\begin{array}{l}\text { Cattle, sheep, goats: } 1 \mathrm{mg} / \mathrm{kg} \\
\text { Others: } 0.5 \mathrm{mg} / \mathrm{kg}\end{array}$ \\
\hline Lead $(\mathrm{Pb})$ & & Complete feed & - & All species: $5 \mathrm{mg} / \mathrm{kg}$ \\
\hline Mercury (Hg) & & Complete feed & - & All species: $0.1 \mathrm{mg} / \mathrm{kg}$ \\
\hline
\end{tabular}

According to NRC for pigs (2012) and cattle (2000).

Table 4 Effects of different essential heavy metals on human health and their specific food sources

\begin{tabular}{|c|c|c|c|}
\hline $\begin{array}{l}\text { Trace } \\
\text { elements }\end{array}$ & Effect associated with human health & Source & Reference \\
\hline Copper (Cu) & $\begin{array}{l}\text { Anemia, liver and kidney damage and stomach and } \\
\text { intestinal irritation }\end{array}$ & Soil contamination & $\begin{array}{l}\text { Thirulogachandar } \\
\text { et al. (2014) }\end{array}$ \\
\hline Nickel (Ni) & $\begin{array}{l}\text { Long-term exposure causes decreased BW, heart and } \\
\text { liver damage and skin irritation }\end{array}$ & $\begin{array}{l}\text { Volcanic activity, industrial and anthropogenic } \\
\text { processes (metal-plating industries, combustion } \\
\text { of fossil fuels, and nickel mining and dredging) }\end{array}$ & EFSA (2015) \\
\hline Iron (Fe) & $\begin{array}{l}\text { Anemia, heart disease, cancer, diabetes, choroiditis, } \\
\text { retinitis and conjunctivitis }\end{array}$ & $\begin{array}{l}\text { Meat, whole meal products, potatoes } \\
\text { and vegetables }\end{array}$ & $\begin{array}{l}\text { Thirulogachandar } \\
\text { et al. (2014) }\end{array}$ \\
\hline Cobalt (Co) & $\begin{array}{l}\text { Sterility, hair loss, vomiting, bleeding, diarrhea, coma } \\
\text { and even death }\end{array}$ & Soil contamination & $\begin{array}{l}\text { Thirulogachandar } \\
\text { et al. (2014) }\end{array}$ \\
\hline $\begin{array}{l}\text { Manganese } \\
\quad(\mathrm{Mn})\end{array}$ & $\begin{array}{l}\text { Languor, sleepiness, weakness, emotional disturbances, } \\
\text { spastic gait, recurring leg cramps and paralysis }\end{array}$ & $\begin{array}{l}\text { Spinach, tea, herbs, grains and rice, soya beans, } \\
\text { eggs, nuts, olive oil, green beans and oysters }\end{array}$ & $\begin{array}{l}\text { Thirulogachandar } \\
\text { et al. (2014) }\end{array}$ \\
\hline
\end{tabular}

be higher for a metal with a moderate toxicity but which is widespread and thus there is a higher risk of exposure. The environmental conditions, such as soil contamination, industrial processes and incorrect manufactory procedures, are responsible for high levels of $\mathrm{Sn}, \mathrm{Cu}, \mathrm{Ni}$ and $\mathrm{Co}$.

\section{Heavy metals in feed/food chain}

Undesirable substances of heavy metals $(\mathrm{Cd}, \mathrm{Pb}, \mathrm{Hg}, \mathrm{As}, \mathrm{Cr})$ as well as essential heavy metals ( $\mathrm{Fe}, \mathrm{l}, \mathrm{Co}, \mathrm{Cu}, \mathrm{Mn}, \mathrm{Mo}, \mathrm{Se}$ ) have potential adverse effects on livestock directly, but can also enter the food chain through animal consumption and thus represent a risk for humans. Concerning the evaluation of exposure levels to toxic metals or to toxic doses, it is important to consider that the dietary intake can be influenced by several factors: management, type and quality of raw materials, additives, soil ingestion and accidental contamination. Episodes of acute toxicity are uncommon, with the exception of accidental exposure. Heavy metals are potentially dangerous due to their toxicity, bioaccumulation and bio-magnification when found within living tissues, and are stored more quickly than they are excreted. Heavy metals are considered contaminants or undesirable substances ( $\mathrm{As}, \mathrm{Cd}, \mathrm{F}, \mathrm{Pb}, \mathrm{Hg}$ ) when they are not intentionally added to food, but may reach the feed and food chains throughout different sources (Jarup, 2003).

The carry-over of orally administered metals into animalorigin food (milk, eggs, meat) (Table 5) is related to the rate of absorption, bioaccumulation, metabolism and excretion (Cheli et al., 2013). These biological phenomena largely vary depending on the chemical form, are dose- and/or time dependent (especially for some bio accumulative elements such as cadmium), and are influenced by other factors such as the interaction with other compounds (e.g. Cd greatly interferes with essential elements such as $\mathrm{Cu}$ and $\mathrm{Zn}$ ) (Fink-Gremmels, 2012).

With regard to $\mathrm{Cd}, \mathrm{Pb}$, As and $\mathrm{Hg}$ different studies showed that the carry-over to milk, egg and muscle is generally low if animals are fed with a standard diet (with a concentration of heavy metals below the EU maximum permissible levels). 
Table 5 Effects of different essential and non-essential heavy metals as contaminants on human health, the specific carry-over effects and their sources

\begin{tabular}{|c|c|c|c|c|c|}
\hline $\begin{array}{l}\text { Heavy metal } \\
\text { contaminants }\end{array}$ & Kind of element & $\begin{array}{l}\text { Effects associated with } \\
\text { human health }\end{array}$ & $\begin{array}{l}\text { Carry-over to animal tissues } \\
\text { and products }\end{array}$ & Source & Reference \\
\hline Chromium (Cr) & EHM & $\begin{array}{l}\text { Skin irritation and ulceration after } \\
\text { acute exposure; kidney and liver } \\
\text { malfunctions and circulatory and } \\
\text { nervous system damage after } \\
\text { long-term exposure }\end{array}$ & No data & $\begin{array}{l}\text { Metal alloys and pigments } \\
\text { and other materials }\end{array}$ & $\begin{array}{l}\text { Wuana and Okieimen } \\
\text { (2011) }\end{array}$ \\
\hline Cadmium (Cd) & NHM & $\begin{array}{l}\text { Kidney and liver damage, skin } \\
\text { irritation, ulceration, enzyme } \\
\text { inactivation, lung cancer }\end{array}$ & $\begin{array}{l}\text { Liver and kidney: dose and } \\
\text { time dependent } \\
\text { Muscle: very low (independent } \\
\text { of the level of dietary } \\
\text { exposure) } \\
\text { Milk and eggs: very low or } \\
\text { absent }(<0.05 \%)\end{array}$ & $\begin{array}{l}\text { Tobacco smoking, whole grain } \\
\text { cereals, fruit, root vegetables } \\
\text { and wild mushrooms, offal } \\
\text { (kidney and liver) of } \\
\text { mammals and shellfish } \\
\text { (oysters and scallops) }\end{array}$ & $\begin{array}{l}\text { Food Safety Authority of } \\
\text { Ireland (2009); EFSA } \\
(2004)\end{array}$ \\
\hline Lead (Pb) & NHM & $\begin{array}{l}\text { Impaired development, lower IQ, } \\
\text { shortened attention span, } \\
\text { hyperactivity, and mental } \\
\text { deterioration in children. } \\
\text { Loss of memory, nausea, } \\
\text { insomnia, anorexia, weakness of } \\
\text { the joints, injury to the brain, } \\
\text { nervous system, red blood cells, } \\
\text { and kidneys in adults }\end{array}$ & $\begin{array}{l}\text { Muscle low and not significant } \\
\text { Milk } 0.1-1 \% \text {. }\end{array}$ & $\begin{array}{l}\text { Leafy vegetables (lettuce), root } \\
\text { crops (carrots), fish and } \\
\text { shellfish offal (liver and } \\
\text { kidney), cereals and tap } \\
\text { water }\end{array}$ & $\begin{array}{l}\text { Wuana and Okieimen } \\
\text { (2011); EFSA (2010) }\end{array}$ \\
\hline Mercury (Hg) & NHM & $\begin{array}{l}\text { Damage to the central nervous } \\
\text { system (neurotoxicity) and } \\
\text { the kidney }\end{array}$ & $\begin{array}{l}\text { Limited information and no } \\
\text { dose-response studies } \\
\text { available }\end{array}$ & Fish and fishery products & $\begin{array}{l}\text { Food Safety Authority of } \\
\text { Ireland (2009) }\end{array}$ \\
\hline Arsenic (As) & NHM & $\begin{array}{l}\text { Skin damage, increased risk of } \\
\text { cancer, and problems with } \\
\text { circulatory system }\end{array}$ & No data & $\begin{array}{l}\text { Fish, seafood (crab) and } \\
\text { animal offal }\end{array}$ & \\
\hline
\end{tabular}

EHM = essential heavy metal; NHM = non-essential heavy metal. 
Conversely, with a higher dietary toxic metal exposure, a general increase in residues in the specific accumulation organs (liver, kidney, bones) has been observed (Thirulogachandar et al., 2014). Thus, the control of the animal input could be an effective strategy to reduce human health risks related to the consumption of animal-origin products.

The accumulation of heavy metals varies significantly from one tissue to another within an animal, and between animals. Higher As concentrations have been detected in breast meat, the essential edible part of poultry; and kidney and gizzard showed the highest content of $\mathrm{Cd}$ and $\mathrm{Cr}$, respectively (Mohammed et al., 2013). A positive correlation between dietary intake and concentration in broiler organs (muscles, liver, and skin) has also been demonstrated for essential metals as Fe and Mn (Rehman et al., 2012).

Among animal products, eggs are also a possible source of heavy metal contamination. Radu-Rusu et al. (2013) compared the heavy metal transferability in improved cages and free-range reared hens, and discovered that free-range eggs had higher concentrations of heavy metals, compared with the conventionally-produced eggs, due to the intense soil contamination with these pollutants. The $\mathrm{Cd}$ level was 0.018 v. $0.023 \mathrm{ppm}$ in the free-range group; 2.591 v. $2.734 \mathrm{ppm}$ for essential $\mathrm{Cu}$, and the essential $\mathrm{Zn}$ content was $5.386 \mathrm{ppm}$ in improved cages v. $5.522 \mathrm{ppm}$.

Ruminants are less susceptible to As toxicosis and do not show any sign of toxicity unless the concentration is more than 200 to $300 \mathrm{mg}$ of inorganic As/kg of feed (Kochare and Tamir, 2015). Dairy cows are more susceptible to the accumulation of $\mathrm{Cd}$ and $\mathrm{Pb}$ than beef cattle, however both suffer from mercury toxicity. This heavy metal, especially in the form of methyl, is highly toxic and can lead to incoordination, decline in awareness, alopecia and visual and gastrointestinal disorders. García-Vaquero et al. (2011) investigated intensively farmed beef cattle and demonstrated that essential $\mathrm{Cu}$ accumulation in the liver had negative effects on animal performance, and found a reduced feed intake and average daily gain. This decreased growth performance may be due to the production of reactive oxygen species following excess supplementation with $\mathrm{Cu}$.

Fish containing the valuable proteins and $n-3$ polyunsaturated fatty acids and could represent source of heavy metal exposure to humans (Nnaji et al., 2011). According to Qiu et al. (2011), heavy metal accumulation in fish tissues depends largely on their concentrations in water, in prey or commercial feed. Dangerous heavy metals of interest include $\mathrm{Hg}$, As which are and carcinogenic. However, heavy metals tend to accumulate more in the visceral tissues of fish (liver, kidney, intestines, etc.), which are normally discarded during the manufacturing processes, than in the muscles (Nnaji et al., 2011). Qiu et al. (2011) found significant relationships between the concentrations of essential $\mathrm{Cu}$ and $\mathrm{Zn}$ and lipid contents in two farmed fish species (pompano and snapper). Their findings indicate that lipid content may be an important factor regulating the bioaccumulation of these metals. $\mathrm{Cu}$ is an essential metal for both fish and humans, however $\mathrm{Cu}$ poisoning induces gill, liver and kidney damage in fish, leading to mortalities.

\section{Mineral nutrition in livestock}

Livestock nutrition plays a pivotal role not only in guaranteeing the animal requirements and thus preventing nutritional deficiency, but also in improving animal health and welfare, productivity, food safety and also in controlling environmental pollution. All animals require mineral nutrition including some heavy metals that have been demonstrated to be essential nutrients. Minerals, such as $\mathrm{Co}, \mathrm{Cu}, \mathrm{Fe}, \mathrm{I}, \mathrm{Mn}, \mathrm{Mo}, \mathrm{Se}$, and $\mathrm{Zn}$, are part of the numerous enzymes that coordinate many biological processes, and consequently are essential to maintain animal health and productivity (Lopez-Alonso et al., 2012a). Essential metals perform four important types of function: structural, physiological, catalytic and regulatory (Suttle, 2010).

Many essential trace elements used in intensive livestock are found in manure, in direct proportion to the quote supplied over the minimal requirements. From a mineral nutrition point of view, and in order to prevent mineral deficiencies that could compromise the production, commercial feeds are often supplemented with minerals in order to promote the optimum growth rate, functional bioactivity and antimicrobial properties. For example, Se is naturally present in many foods, such as yeast. It plays a critical role in reproduction, DNA synthesis, hormone metabolism and protects the body from infection, oxidative damage and has an important bioactive role related to a decrease in the susceptibility to carcinogens (Dai et al., 2016).

Farmers usually balance animal diets with minerals according to the maximum acceptable levels established by EU authorities. Nevertheless, the maximum permitted amount in feed is usually greater than the minimum requirement, resulting in the wide diffusion of minerals into the environment. For example, the minimum nutrient requirement for $\mathrm{Zn}$ (NRC, 2012) ranges between 50 and $100 \mathrm{ppm}$ in different grow phases, however it is often used as an additive thus taking the level to $150 \mathrm{ppm}$, which is the maximum acceptable level established by the European authorities.

Although, the net requirements of essential metals are lower than the dietary needs, different aspects need to be considered in order to establish the optimal concentration in feed: genetic influences, dietary factors, interaction among nutrients, bioavailability and subclinical toxic effects. The optimal mineral supplementation, which is represented as a band between the adequate and inadequate toxic dietary concentration established by the dose/response, should also consider unnecessary levels excreted into the environment. The ban on antibiotic growth promoters (EU Reg. 1831/2003) in livestock led to the study of alternative compounds (Rossi et al., 2013 and 2014a), however it increased the use of some minerals as growth stimulants and to prevent enteric diseases in pigs.

High doses of $Z n$ in the form of premix have thus been widely used in several EU countries. Zn is essential in the maintenance and restoration of barrier integrity, protection 
against pathogens and modulation of the immune system, promoting antibody production against intestinal pathogens (Rossi et al. 2014c). In addition, Zn may reduce diarrhea and increase growth rates in weaning piglets (Sales, 2013; Walk et al., 2015). Although the pharmacological use of $\mathrm{Zn}(2500$ to $3000 \mathrm{mg}$ of $\mathrm{Zn} / \mathrm{kg}$ ), available with a veterinary prescription, can reduce intestinal disorders after the weaning of pigs, from a nutritional and ecological point of view, a better strategy would be to identify and counter the main cause of diarrhea (Rossi et al. 2014c).

$\mathrm{Cu}$ is another important mineral that is profoundly connected with livestock production. When this trace element is added to the diet of fattening pigs, it causes a faster growth and better feed-conversion ratio (Polen and Voia, 2015). In pigs, dietary concentrations of 150 to $250 \mathrm{mg}$ of $\mathrm{Cu} / \mathrm{kg}$ can maximize growth performance without exposing animals to any risk of poisoning. Also in poultry production $\mathrm{Cu}, \mathrm{Zn}$ and $\mathrm{Mn}$ prevents some diseases: Cu prevents anemia, whereas $\mathrm{Zn}$ and $\mathrm{Mn}$ act as catalysts in many enzymatic and hormonal reactions (Suleiman et al., 2015).

Although corn tissues cultivated in soil with high amounts of $\mathrm{Cu}$ do not accumulate it at toxic levels, Cu represents an environmental concern, and can enter into the human food chain by accidental soil ingestion, contamination of edible plants by soil, or by the consumption of contaminated products of an animal food origin (Alfthan et al., 2015).

In order to develop a sustainable nutritional strategy, the maximum permissible levels should not be considered as optimal, and mineral supplementation should be established in terms of the desirable limits, which should be lower than the legal ones (Eu et al., 2007).

In conventional farms, minerals can be supplemented in different forms. Inorganic salts, such as sulphates, carbonates, chlorides and oxides, are the most common ones. When ingested, these salts are broken down in the digestive tract to form free ions which are then absorbed (Lopez-Alonso, 2012a). In order to ensure the extranutritional effect of some elements on animals, the concentrations of these salts often exceed the physiological requirements, causing fecal excretion. Thus, there has been increasing interest in chelated compounds as hyperavailable mineral sources, thus reducing the dispersal of minerals in manure. Various studies have shown that chelated minerals can be included at much lower levels without compromising performance, minimizing nutrient excretion and the overall environmental impact (Lopez-Alonso, 2012b). However more light needs to be showed on this matter, in fact fecal $\mathrm{Zn}$ excretion is related to the dietary $\mathrm{Zn}$ concentration rather than the source.

For an optimal mineral supplementation, the various interactions among minerals and diet components need to be considered. Positive and negative nutrient interactions, involve the impact of the nutrient on another nutrient's bioavailability, including absorption and use. For example, $\mathrm{Cu}$ interacts mainly negatively with $\mathrm{Mn}, \mathrm{Zn}$ and Fe (García-Vaquero et al., 2011).

Various proteins bind and carry certain minerals including $\mathrm{Fe}, \mathrm{Cu}$ and $\mathrm{Ca}$ and thus an inadequate protein intake may impair the function of these nutrients (Collins et al., 2010). The quality and quantity of dietary fiber can negatively influence the absorption of several minerals, including $\mathrm{Ca}$ and $\mathrm{Fe}$. In monogastric animals, phytic acid, found in cereals and legumes, can bind minerals to insoluble complexes, thus decreasing the absorption of $2+$ chemical configurations. The interaction of vitamins and minerals has also been described in several metabolic situations and is still under investigation. Many trace elements are recognized as oxidants, which may deteriorate animal feed, in particular during long-term storage at high temperatures (Medardus et al., 2014).

A well-balanced diet is generally recommended in order to meet the requirements of all nutrients, considering possible interactions among nutrients, preventing deficiencies and chemical excesses or imbalances. For sustainable animal production and to develop effective approaches to preserving long-term soil and water quality strategies from heavy metal pollution, it is necessary to understand the nutritional basis of the interactions between organisms and the environment.

\section{Heavy metals in feed: worldwide situation}

Farming practices vary widely according to the global soil and climatic conditions, thus heavy metal contamination in feed can have divergent concentrations and strictly depends on the location and legal restrictions (Table 6).

To be able to predict the risk of exposure to toxic doses of metals, it is important to consider the production system. Extensive ruminant farms, both beef cattle and dairy, need land to produce forage (hay, straw and silage) as energy sources for the ruminal symbiotic microflora (Zaninelli et al., 2015). Naturally, all soils contain different concentrations of heavy metals. Furthermore, such components are also added to agricultural soils through the application of mineral and organic fertilizers, direct defecation and urination by animals, and pesticides (Kochare and Tamir 2015). In these cases, exposure in animals may vary in relation to the quality of the soil, the use of inorganic fertilizers and anthropogenic activities. Animals in intensive systems usually receive concentrate feed, with raw materials from a global market supplemented by mineral additives. By accurate monitoring in intensive systems, the control of the input of heavy metals is easier than in extensive systems.

Feed additives are widely applied in animal production in all described locations and $\mathrm{Cu}$ and $\mathrm{Zn}$ are present in feeds largely. The content of heavy metals, especially $\mathrm{Cu}$ and $\mathrm{Zn}$ in swine feed has been found to be higher than in poultry feed or in cattle feed. According to Dai et al. (2016) more than half of the Wisconsin (USA) dairy farms used feed rations containing $\mathrm{Cu}$ above the recommended levels. Zhang et al. (2012) reported that in north-east $\mathrm{China} \mathrm{Cu}, \mathrm{Zn}$ and As were found in all feed samples. According to Wang et al. (2013) in China (Jiangsu Province), median concentrations of Zn were the highest heavy metals found, followed by $\mathrm{Cu}$. The median concentrations of undesirable substances such as $\mathrm{Hg}, \mathrm{As}, \mathrm{Pb}$, $\mathrm{Cd}$ and $\mathrm{Cr}$ in all feeds were below $10 \mathrm{mg} / \mathrm{kg}$ (Table 6). This is probably related to the different management of raw materials and feed, animal species as well as different legal limits. 
Hejna, Gottardo, Baldi, Dell'Orto, Cheli, Zaninelli and Rossi

Table 6 Comparison of content of heavy metals in feed in the USA, China and England and Wales (EW)

\begin{tabular}{|c|c|c|c|c|}
\hline Sources & Heavy metal & Kind of element & Concentration & Reference \\
\hline \multirow[t]{20}{*}{ Dairy feed } & As & US & 11 to $33 \mathrm{mg} / \mathrm{kg}$ & Dai et al. (2016) - USA \\
\hline & & & 0.01 to $6.123 \mathrm{mg} / \mathrm{kg}$ & Zhang et al. (2012) - China \\
\hline & & & $<10 \mathrm{mg} / \mathrm{kg}$ & Wang et al. (2013) - China \\
\hline & & & 0.1 to $4.13 \mathrm{mg} / \mathrm{kg}$ & Nicholson et al. (2003) - EW \\
\hline & $\mathrm{Cd}$ & US & 5 to $82 \mathrm{ppb}$ & Dai et al. (2016) - USA \\
\hline & & & $\mathrm{Nd}$ to $23.25 \mathrm{mg} / \mathrm{kg}$ & Zhang et al. (2012) - China \\
\hline & & & $<10 \mathrm{mg} / \mathrm{kg}$ & Wang et al. (2013) - China \\
\hline & & & 0.1 to $3.59 \mathrm{mg} / \mathrm{kg}$ & Nicholson et al. (2003) - EW \\
\hline & $\mathrm{Pb}$ & US & 12 to $349 \mathrm{mg} / \mathrm{kg}$ & Dai et al. (2016) - USA \\
\hline & & & $<10 \mathrm{mg} / \mathrm{kg}$ & Wang et al. (2013) - China \\
\hline & & & 1.0 to $8.23 \mathrm{mg} / \mathrm{kg}$ & Nicholson et al. (2003) - EW \\
\hline & $\mathrm{Cu}$ & EHM & $37.8 \mathrm{mg} / \mathrm{kg}$ & Dai et al. (2016) - USA \\
\hline & & & 2.73 to $114.68 \mathrm{mg} / \mathrm{kg}$ & Zhang et al. (2012) - China \\
\hline & & & $15.7 \mathrm{mg} / \mathrm{kg}$ & Wang et al. (2013) - China \\
\hline & & & 2 to $21.3 \mathrm{mg} / \mathrm{kg}$ & Nicholson et al. (2003) - EW \\
\hline & $\mathrm{Cr}$ & EHM & $4.91 \mathrm{mg} / \mathrm{kg}$ & Dai et al. (2016) - USA \\
\hline & & & $<10 \mathrm{mg} / \mathrm{kg}$ & Wang et al. (2013) - China \\
\hline & $\mathrm{Zn}$ & EHM & 11.07 to $346.12 \mathrm{mg} / \mathrm{kg}$ & Zhang et al. (2012) - China \\
\hline & & & $73.0 \mathrm{mg} / \mathrm{kg}$ & Wang et al. (2013) - China \\
\hline & & & 6 to $83 \mathrm{mg} / \mathrm{kg}$ & Nicholson et al. (2003) - EW \\
\hline \multirow[t]{11}{*}{ Pig feed } & As & US & 0.02 to $13.03 \mathrm{mg} / \mathrm{kg}$ & Zhang et al. (2012) - China \\
\hline & & & $<10 \mathrm{mg} / \mathrm{kg}$ & Wang et al. (2013) - China \\
\hline & $\mathrm{Cd}$ & US & $\mathrm{Nd}$ to $31.65 \mathrm{mg} / \mathrm{kg}$ & Zhang et al. (2012) - China \\
\hline & & & $<10 \mathrm{mg} / \mathrm{kg}$ & Wang et al. (2013) - China \\
\hline & $\mathrm{Cu}$ & EHM & $169.9 \mathrm{mg} / \mathrm{kg}$ & Dai et al. (2016) - USA \\
\hline & & & 2.3 to $1.137 \mathrm{mg} / \mathrm{kg}$ & Zhang et al. (2012) - China \\
\hline & & & $36.9 \mathrm{mg} / \mathrm{kg}$ & Wang et al. (2013) - China \\
\hline & & & 18 to $217 \mathrm{mg} / \mathrm{kg}$ & Nicholson et al. (2003) - EW \\
\hline & $\mathrm{Zn}$ & EHM & 37.37 to $598.32 \mathrm{mg} / \mathrm{kg}$ & Zhang et al. (2012) - China \\
\hline & & & $103.3 \mathrm{mg} / \mathrm{kg}$ & Wang et al. (2013) - China \\
\hline & & & 150 to $2920 \mathrm{mg} / \mathrm{kg}$, & Nicholson et al. (2003) - EW \\
\hline \multirow[t]{9}{*}{ Poultry feed } & $\mathrm{Cu}$ & EHM & $132.7 \mathrm{mg} / \mathrm{kg}$ & Dai et al. (2016) - USA \\
\hline & & & 2.88 to $98.08 \mathrm{mg} / \mathrm{kg}$ & Zhang et al. (2012) - China \\
\hline & & & $17.0 \mathrm{mg} / \mathrm{kg}$ & Wang et al. (2013) - China \\
\hline & & & 24.8 to $52.4 \mathrm{mg} / \mathrm{kg}$ (broiler) & Nicholson et al. (2003) - EW \\
\hline & & & 13.23 to $49.7 \mathrm{mg} / \mathrm{kg}$ (Turkey) & \\
\hline & $\mathrm{Zn}$ & EHM & 52.62 to $150.97 \mathrm{mg} / \mathrm{kg}$ & Zhang et al. (2012) - China \\
\hline & & & $99.1 \mathrm{mg} / \mathrm{kg}$ & Wang et al. (2013) - China \\
\hline & & & 106 to $169 \mathrm{mg} / \mathrm{kg}$ (broiler) & Nicholson et al. (2003) -EW \\
\hline & & & 102 to $210 \mathrm{mg} / \mathrm{kg}$ (Turkey) & \\
\hline
\end{tabular}

US $=$ undesirable substances in animal feed; $\mathrm{EHM}=$ essential heavy metal; $\mathrm{Nd}=$ non-detectable. $\mathrm{EW}=$ England and Wales.

The concentration of toxic undesirable metals, such as $\mathrm{Cd}$ and $\mathrm{Pb}$, was higher in forage than in concentrate feed materials and in particular in herbage cultivated near industrial areas. This is probably related to the contamination of forage with soil and not to the plant uptake. Instead, the main sources of As and $\mathrm{Hg}$ in feeds are represented by non-plant materials such as products of marine origin.

\section{Heavy metals in livestock manure}

Heavy metals can be introduced into agricultural soil through manure. The input of organic waste to agricultural soil increases organic matter, introduces nutrients, improves soil structure and increases nutrient absorption by plants, which improves soil fertility and quality (Gul et al., 2015). Despite, the considerable fertilizer value of slurry, it may be abundant in $\mathrm{Zn}, \mathrm{Cu}$ and other heavy metals derived from animal intake (Jakubus et al., 2013). The heavy metal composition of composts varies widely depending on the geographical location, sources and composting process (Faridullah et al., 2014).

Ingelmo et al. (2012) reported on digested sewage sludge (collected from Spanish farms), during the compost process. They found that the heavy metal content varies and total $Z n$, $\mathrm{Pb}, \mathrm{Cu}$ and $\mathrm{Ni}$ content increased during the composting process. On the final composting day, the content was ranked $\mathrm{Zn}>\mathrm{Pb}>\mathrm{Cu}>\mathrm{Ni}>\mathrm{Cd}$ (Table 7). Thus, the total content of heavy metals depends on the organic matter transformation, which may influence the bioavailability of 
Table 7 Essential and non-essential heavy metal content $(\mathrm{mg} / \mathrm{kg})$ in sludge-based compost on different days of composting

\begin{tabular}{lrrrr}
\hline \hline Time (days) & \multicolumn{1}{c}{0} & \multicolumn{1}{c}{14} & \multicolumn{1}{c}{84} & \multicolumn{1}{c}{140} \\
\hline $\mathrm{Cu}(\mathrm{EHM})$ & 37.70 & 41.30 & 43.10 & 49.50 \\
$\mathrm{Ni}(\mathrm{EHM})$ & 2.24 & 2.38 & 2.69 & 2.76 \\
$\mathrm{Zn}(\mathrm{EHM})$ & 259.80 & 262.10 & 267.10 & 278.20 \\
$\mathrm{~Pb}(\mathrm{NHM})$ & 45.30 & 49.50 & 53.70 & 57.40 \\
\hline \hline
\end{tabular}

EHM = essential heavy metal; NHM = non-essential heavy metal. Ingelmo et al. (2012).

metals and in the end render the metals in more available forms.

Faridullah et al. (2014) have shown that acid-extracted metals were also higher in composted manure than fresh manure. The authors collected animal-composted waste samples (Abbottabad District, Pakistan). They were ranked $\mathrm{Fe}>\mathrm{Hg}>\mathrm{Mn}>\mathrm{Zn}>\mathrm{Ni}$. In addition, $\mathrm{Fe}, \mathrm{Mn}$ and $\mathrm{Hg}$ concentrations were higher in the composted manures, whereas $\mathrm{Ni}$ and $\mathrm{Zn}$ showed their maximum concentrations in fresh manures. The maximum Fe concentration was detected in composted buffalo manure. Faridullah et al. (2014) observed a different trend in metal extraction. The high content of $\mathrm{Fe}$ was related to the different feed composition or products of fish origin.

According to Jakubus et al. (2013) tested slurries (collected from Dutch farms) containing Cu and Zn were from 1.5 to 3.0 times higher in swine slurry than cattle slurry. Nicholson et al. (2003) showed that in England and Wales, the highest metal concentrations for swine and cattle and poultry livestock manures were $\mathrm{Zn}$ and $\mathrm{Cu}$. In sewage sludge the highest concentrations of heavy metals were also $\mathrm{Zn}, \mathrm{Cu}$ and also $\mathrm{Pb}, \mathrm{Cr}$.

In China, the highest concentrations for swine livestock manures were: $\mathrm{Zn}, \mathrm{Cu}, \mathrm{Cr}$ and $\mathrm{Pb}$; and for cattle manures: $\mathrm{Zn}$, $\mathrm{Cu}, \mathrm{Pb}$ and $\mathrm{Cr}$. The contents of trace elements in animal manures increased over a decade, with the use of feed additives (Luo et al., 2009). Zhang et al. (2012) showed that in north-east China, the contents of $\mathrm{Cu}$ and $\mathrm{Zn}$ in manures of different size farms (small, medium and large farms) were significantly higher than other metals detected. In cattle and chicken manure, there was no significant difference in the content of heavy metals from farms of different sizes (Table 8). In China, in the last decade an increase in the content of $Z n$ in manure has been found. This is related to the high content of $\mathrm{Zn}$ in animal additives, which have usually resulted in a higher concentration in the manure.

The heavy metal contents of animal manures are largely a reflection of their content in the feed, which poses a high pollution risk to farmlands. Considering the different kinds of farms and different species, swine and poultry represent the most important sources of $\mathrm{Zn}$ and Cu pollution. This is also linked to the additives used in animal feed (Nicholson et al., 2003; Luo et al., 2009; Zhang et al., 2012, Jakubus et al., 2013). Consequently, swine and poultry farms may have the highest risk for agricultural lands. In terms of environmental protection, animal feed additives should be monitored based on the legal limits in each country (Zhang et al., 2012).
Different approaches are also needed for reducing heavy metal inputs to agricultural land and to target policies for preserving long-term soil quality (Nicholson et al., 2003).

\section{Heavy metal content in agricultural soil}

The soil represents an important risk in terms of the livestock exposure to heavy metals due to accidental ingestion, contamination of forage, and absorption by edible plants. In most EU member states, but also in the rest of the world, complete inventories of soil are lacking. Quantifying the full extent of local soil pollution is therefore difficult, although this is an important further objective of the EU in the proposed Soil Framework Directive. According to the European Environment Agency (2006) measurements, there were a total of three million potentially contaminated locations in the EU, of which 250 thousand were actually contaminated (Dir. 2004/35/EC). Therefore, reducing heavy metal contamination in the soil is a strategic target for EU soil protection policies (Nicholson et al., 2003).

In various parts of the world widely different levels of trace elements in the agricultural industry have been observed. $\mathrm{Zn}$ pollution has become a general global problem. Zn contamination has reported in all described locations (Nicholson et al., 2003; Luo et al., 2009; Belon et al., 2012) (Table 9). In fact, $\mathrm{Zn}$ is monitored by authorities as it is responsible for eutrophication and water pollution. Depending on the country, there are main sources of $\mathrm{Zn}$ pollution: atmospheric deposition and livestock manure. The livestock industry contributes to $\mathrm{Zn}$ pollution as it is widely used in animal feed as additives. Authorities should thus monitor the pollution and create new strategies for the improved management of animal nutrition. This would help to prevent soil contamination and to build an approach based on ecological nutrition, which could remain sustainable development between economic development, social development and environmental protection. The pressure on agricultural land in China is almost nine times higher for Zn (187 742 g/ha per year) and more than 14 times higher for $\mathrm{Cu}(71824 \mathrm{~g} / \mathrm{ha}$ per year) compared with Germany ( $\mathrm{Zn}-21237 \mathrm{~g} / \mathrm{ha}$ per year) and France ( $\mathrm{Cu}-4869 \mathrm{~g} / \mathrm{ha}$ per year) which have the highest annual input of $\mathrm{Zn}$ and $\mathrm{Cu}$ in the total area of agricultural land, in all described countries in Europe. These differences between China and Europe are probably related to different legal restrictions.

In the EU in terms of the entire agricultural land area, atmospheric deposition has been reported to be the main source of most metals, ranging from $25 \%$ to $85 \%$ of total inputs (Nicholson et al., 2003). According to Luo et al. (2009), in China atmospheric deposition and livestock manures were also the predominant sources of trace elements in agricultural land. In agricultural soils in China, atmospheric deposition may be responsible for $43 \%$ to $85 \%$ of the total As, $\mathrm{Cr}, \mathrm{Hg}, \mathrm{Ni}$ and $\mathrm{Pb}$ inputs. The average atmospheric deposition flux of As in China is about 100 times higher than that in Europe. These sources are related to agricultural and industrial activities (Belon et al., 2012) (Table 10). 
Hejna, Gottardo, Baldi, Dell'Orto, Cheli, Zaninelli and Rossi

Table 8 Concentration of different essential and non-essential heavy metals in selected livestock manures in different countries

\begin{tabular}{|c|c|c|c|c|c|c|c|c|}
\hline \multirow[b]{2}{*}{ Areas } & & \multirow{2}{*}{\multicolumn{2}{|c|}{ Heavy metal }} & \multirow[b]{2}{*}{ Kind of element } & \multicolumn{4}{|c|}{ Source of heavy metals } \\
\hline & & & & & $\begin{array}{l}\text { Cattle } \\
\text { slurry }\end{array}$ & $\begin{array}{l}\text { Swine } \\
\text { slurry }\end{array}$ & Poultry slurry & $\begin{array}{l}\text { Buffalo } \\
\text { Slurry }\end{array}$ \\
\hline \multirow{2}{*}{$\begin{array}{l}\text { The Netherlands } \\
\text { (Jakubus et al., 2013) }\end{array}$} & $\mathrm{Zn}$ & d.m. & & EHM & 73.7 & 186.2 & - & - \\
\hline & $\mathrm{Cu}$ & & & & 296.3 & 644.7 & - & - \\
\hline \multirow{5}{*}{$\begin{array}{l}\text { England and Wales } \\
\text { (Nicholson et al., 2003) }\end{array}$} & $\mathrm{Zn}$ & mg/kg d.m. & & EHM & 170.0 & 650.0 & 217.0 & - \\
\hline & $\mathrm{Cu}$ & & & & 45.0 & 470.0 & 32.0 & - \\
\hline & $\mathrm{Ni}$ & & & & 6.0 & 14.0 & 4.0 & - \\
\hline & $\mathrm{Cr}$ & & & & 6.0 & 7.0 & 2.0 & - \\
\hline & $\mathrm{Pb}$ & & & NHM & 7.0 & 80.0 & 3.3 & - \\
\hline \multirow[t]{10}{*}{ Pakistan (Faridullah et al., 2014) } & $\mathrm{Zn}$ & mg/kg d.m. & $\mathrm{CM}$ & EHM & 163.0 & - & 187.0 & 145.0 \\
\hline & & & FM & & 150.0 & - & 160.0 & 170.0 \\
\hline & $\mathrm{Mn}$ & & $\mathrm{CM}$ & & 430.9 & - & 466.1 & 475.3 \\
\hline & & & FM & & 437.0 & - & 438.0 & 456.7 \\
\hline & $\mathrm{Fe}$ & & $\mathrm{CM}$ & & 1825.5 & - & 1873.0 & 2147.0 \\
\hline & & & FM & & 1664.0 & - & 1806.3 & 1821.2 \\
\hline & $\mathrm{Ni}$ & & $\mathrm{CM}$ & & 71.7 & - & 66.2 & 83.9 \\
\hline & & & FM & & 74.2 & - & 74.0 & 81.5 \\
\hline & $\mathrm{Hg}$ & & $\mathrm{CM}$ & NHM & 771.4 & - & 787.0 & 788.3 \\
\hline & & & FM & & 783.7 & - & 758.5 & 728.3 \\
\hline \multirow[t]{3}{*}{ China (Luo et al., 2009) } & $\begin{array}{l}\mathrm{Zn} \\
\mathrm{Cu}\end{array}$ & mg/kg d.m. & & EHM & $\begin{array}{r}151.9 \\
46.5\end{array}$ & $\begin{array}{l}843.3 \\
472.6\end{array}$ & $\begin{array}{l}308.9 \\
102.0\end{array}$ & $\begin{array}{l}- \\
-\end{array}$ \\
\hline & $\mathrm{Cr}$ & & & & 15.2 & 46.6 & 46.0 & - \\
\hline & $\mathrm{Pb}$ & & & NHM & 15.7 & 10.1 & 20.6 & - \\
\hline \multirow[t]{11}{*}{ China (Zhang et al., 2012) } & $\mathrm{Cu}$ & mg/kg d.m. & $\begin{array}{l}S \\
M\end{array}$ & EHM & $\begin{array}{l}30.8 \\
31.0\end{array}$ & $\begin{array}{l}958.8 \\
420.4\end{array}$ & $\begin{array}{l}51.6 \\
57.2\end{array}$ & $\begin{array}{l}- \\
-\end{array}$ \\
\hline & & & $\mathrm{L}$ & & 31.4 & 612.2 & 87.1 & - \\
\hline & $\mathrm{Zn}$ & & $S$ & & 119.1 & 674.7 & 268.2 & - \\
\hline & & & M & & 126.3 & 476.0 & 241.7 & - \\
\hline & & & $\mathrm{L}$ & & 136.1 & 691.6 & 384.2 & - \\
\hline & $\mathrm{Cr}$ & & $S$ & & 1.3 & 2.7 & 16.6 & - \\
\hline & & & M & & 1.1 & 4.2 & 224.8 & - \\
\hline & & & $\mathrm{L}$ & & 0.2 & 6.6 & 23.7 & - \\
\hline & $\mathrm{Pb}$ & & $S$ & NHM & 1.9 & 2.9 & 2.2 & - \\
\hline & & & $M$ & & 2.2 & 2.5 & 4.9 & - \\
\hline & & & $\mathrm{L}$ & & 2.7 & 2.4 & 4.4 & - \\
\hline
\end{tabular}

$\mathrm{CM}=$ composted manure; $\mathrm{FM}=$ fresh manure; $\mathrm{S}=$ small; animal population (head): cattle $<100$, chicken $<2000$, swine $<200 ; \mathrm{M}=$ middle; animal population (head): cattle 100 to 300, chicken $>2000$, swine 200 to 800 ; $L=$ large; animal population (head) : cattle $>300$, chicken $>20000$, swine $>800$; EHM = essential heavy metal; $\mathrm{NHM}=$ non-essential heav metals; d.m. $=$ dry matter.

Table 9 Comparison of annual input of essential and non-essential heavy metals in soil for one million of ha (mln ha) yearly in various countries

\begin{tabular}{|c|c|c|c|c|c|c|}
\hline \multirow[b]{2}{*}{ Total area of land (million ha) } & $\mathrm{Cu}(\mathrm{g} / \mathrm{ha})$ & $\mathrm{Cr}$ (g/ha) & $\mathrm{Ni}(\mathrm{g} / \mathrm{ha})$ & Zn (g/ha) & $\mathrm{Cd}(\mathrm{g} / \mathrm{ha})$ & $\mathrm{Pb}(\mathrm{g} / \mathrm{ha})$ \\
\hline & \multicolumn{4}{|c|}{ EHM } & \multicolumn{2}{|c|}{ NHM } \\
\hline $\mathrm{CH}-122$ & 588.7 & 139.9 & 86.2 & 1538.9 & 11.6 & 238.2 \\
\hline$F R-29$ & 167.9 & 34.5 & 19.6 & 523.8 & 1.9 & 24.0 \\
\hline $\mathrm{GR}-17$ & 269.2 & - & - & 1249.2 & 4.9 & 86.1 \\
\hline UK - 11.1 & 146.0 & 29.5 & 26.9 & 453.9 & 3.6 & 70.1 \\
\hline $\mathrm{NL}-2$ & 294.0 & - & - & 684.5 & 4.5 & 80.4 \\
\hline SW - 1.1 & 298.2 & - & - & 768.2 & 1.8 & 74.5 \\
\hline
\end{tabular}

$\mathrm{EHM}=$ essential heavy metal; $\mathrm{NHM}=$ non-essential heavy metal; $\mathrm{CH}=\mathrm{China}$; $\mathrm{FR}=$ France; $\mathrm{GR}=$ Germany; $\mathrm{NL}=$ the Netherlands; $\mathrm{SW}=\mathrm{Switzerland}$. Adapted from Nicholson et al. (2003); Luo et al. (2009); Belon et al. (2012). 
Review: Nutritional ecology of heavy metals

Table 10 Essential and non-essential heavy metals in atmospheric deposition rate yearly in the UK (Nicholson et al., 2003), France (FR) (Belon et al., 2012) and China (CH) (Luo et al., 2009)

\begin{tabular}{|c|c|c|c|c|c|c|}
\hline \multirow[b]{2}{*}{ Atmospheric deposition rate (mean) } & $\mathrm{Cu}(\mathrm{g} / \mathrm{ha})$ & $\mathrm{Cr}$ (g/ha) & $\mathrm{Ni}(\mathrm{g} / \mathrm{ha})$ & Zn (g/ha) & \multirow[t]{2}{*}{ As (g/ha) } & $\mathrm{Pb}$ (g/ha) \\
\hline & \multicolumn{4}{|c|}{ EHM } & & \\
\hline UK & 57.0 & 7.5 & 16.0 & 221.0 & 3.1 & 54.0 \\
\hline FR & 8.0 & 2.4 & 0.5 & 55.8 & 0.5 & 7.7 \\
\hline $\mathrm{CH}$ & 108.0 & 61.0 & 58.0 & 647.0 & 28.0 & 202.0 \\
\hline
\end{tabular}

$\mathrm{EHM}=$ essential heavy metal; $\mathrm{NHM}=$ non-essential heavy metal.

In England, livestock manure and sewage sludge are also important sources, responsible for an estimated $37 \%$ to $40 \%$ and $8 \%$ to $17 \%$ of total $\mathrm{Zn}$ and $\mathrm{Cu}$ inputs. According to Belon et al. (2012) in France animal manure, mineral fertilizers and pesticides are the predominant sources of heavy metals. Livestock manure was the predominant $(>50 \%)$ source of $\mathrm{Zn}, \mathrm{Cu}, \mathrm{Mo} \mathrm{Ni}, \mathrm{As}$, and $\mathrm{Hg}$.

Although the toxic metal concentration in feedstuff from unpolluted soil has been found to be in line with the safety limits established by the EU, a renewed inventory of metal inputs into agricultural soils is of immense importance in order to assess the environmental risks posed by contaminated agricultural soils (Luo et al., 2009).

\section{Strategies to control heavy metal pollution}

Controlling environmental losses and the spread of contaminants from livestock manure is essential in balanced production systems and in order to achieve the homeostasis of agriculture with natural habitats. Although, as in most European countries, spreading manure near to surface water and on frozen soil is illegal, the accidental release of farm waste to water has resulted in outbreaks of serious illnesses. There is thus is a need for technologies and strategies to control these environmental problems. Efforts are also needed to close nutrient cycles on farms by recycling nutrients in livestock manure which will reduce pollution problems and limit heavy metals in soil (Petersen et al., 2007; Gerber et al., 2014). Therefore, many studies have described strategies to control the content of heavy metals in livestock manure and in soil. Effective strategies should focus on a reduction in the heavy metal input/output ratio in livestock. Thus, different multidisciplinary approaches should be considered to reduce the animal intake, but also the excretion in feces and the concentration in manure.

The manipulation of the diet could be a useful way to control the amount of manure produced together with its composition, because nutrients found in manure or in compounds derive from the fraction of the feed that is not absorbed by the animals. A formulated diet is needed that increases the efficiency of nutrient retention by animals, decreasing their excretion in feces and urine and reduce the import of nutrients in feed and mineral mixtures from outside the farm (Petersen et al., 2007). For instance, in pigs and poultry, the use of industrial amino acids is a very efficient way to reduce nitrogen excretion. At the farm level this thus leads to a significant reduction in the import of protein rich feedstuffs, such as soybean meal. The inclusion of enzymes in the feed which improves the biological availability of some specific nutrients has been shown to be efficient in many species. Animal feeding plays an important role in the control of nutrient flows on livestock farms (Petersen et al., 2007). Using mineral supplements of trace minerals could help prevent the 'waste'. The maximum permitted level should not be considered as the ideal level for animal requirement and alternative innovative compounds to antibiotics but also to $\mathrm{Zn}$ and $\mathrm{Cu}$ should be used to control enteric diseases (Rossi et al., 2014b).

An excessive heavy metal output still can penetrate the soil and water from manures, thus there is a need for different technologies to remove the content of heavy metals from contaminated soil and water in agricultural land (He et al., 2005). To reduce the heavy metal output from livestock, different approaches to treat the manure have been studied and can be applied in the field.

Electroremediation which passes an electric current through liquid manure and metal ions are precipitated on an electrode, can reduce metal concentrations. However, at present the technology is unproven at the farm-scale and is unlikely to be cost-effective. From a whole-farm perspective, the recycling loop of manure back into food production should be as short as possible in order to minimize the environmental impact and ensure a high nutrient efficiency (Petersen et al., 2007).

According to Bhargava et al. (2012) phytoremediation is simple cleanup technology which has promising possibilities to eliminate metals from agricultural land, through the use of plants that accumulate large amounts of heavy metal contaminants. This technology was developed a few decades ago from the recognition that plants were capable of metabolizing toxic pesticides (Van Aken, 2009). It is perceived as an acceptable, cost-effective and efficient, novel technology with acceptability among the communities. Phytoremediation comprises several techniques that use plants and associated microbes to remediate contaminated matrices, which are removed through transfer, containment, accumulation or dissipation. The fact that phytoremediation is usually carried out in situ contributes to its cost-effectiveness and may reduce the exposure of the polluted substrate to humans, wildlife and the environment (Pilon-Smits, 2005). Depending on the conditions, the level of clean-up required, the plants used and the contaminants, phytoremediation can be divided into four types: phytoextraction, phytofiltration, phytostabilization and phytovolatilization (Thangavel and Subbhuraam, 2004; Ali et al., 2013). 
The manipulation of the diet could be a useful way to control the amount of manure produced together with its composition, because nutrients found in manure or in compounds derive from the fraction of the feed that is not absorbed by the animals. A formulated diet is needed that reduces the efficiency of nutrient retention by animals, increases their excretion in feces and urine and decreases the import of nutrients in feed and mineral mixtures from outside the farm (Petersen et al., 2007). For instance, in pigs and poultry, the use of industrial amino acids is a very efficient way to reduce nitrogen excretion. At the farm level this thus leads to a significant reduction in the import of protein rich feedstuffs, such as soybean meal. The inclusion of enzymes in the feed which improves the biological availability of some specific nutrients has been shown to be efficient in many species. Animal feeding plays an important role in the control of nutrient flows on livestock farms (Petersen et al., 2007). Using mineral supplements of trace minerals could help prevent the 'waste'. The maximum permitted level should not be considered as the ideal level for animal requirement and alternative innovative compounds to antibiotics but also to $\mathrm{Zn}$ and $\mathrm{Cu}$ should be used to control enteric diseases (Rossi et al., 2014b).

An excessive heavy metal output still can penetrate the soil and water from manures, thus there is a need for different technologies to remove the content of heavy metals from contaminated soil and water in agricultural land. To reduce the heavy metal output from livestock, different approaches to treat the manure have been studied and can be applied in the field.

Electroremediation which passes an electric current through liquid manure and metal ions are precipitated on an electrode, can reduce metal concentrations. However, at present the technology is unproven at the farm-scale and is unlikely to be cost-effective. From a whole-farm perspective, the recycling loop of manure back into food production should be as short as possible in order to minimize the environmental impact and ensure a high nutrient efficiency.

According to Bhargava et al. (2012) phytoremediation is simple cleanup technology which has promising possibilities to eliminate metals from agricultural land, through the use of plants that accumulate large amounts of heavy metal contaminants. This technology was developed a few decades ago from the recognition that plants were capable of metabolizing toxic pesticides (Van Aken, 2009). It is perceived as an acceptable, cost-effective and efficient, novel technology with acceptability among the communities. The proper plants for removal heavy metals should have the following components: (i) high growth rate, (ii) highly branched and widely distributed root system, (iii) good adaptation to prevailing environmental and climatic conditions, (iv) easy cultivation and harvest, (v) production of more above-ground biomass, (vi) resistance to pathogens and pests, (vii) more accumulation of the target heavy metals from soil, (viii) translocation of the accumulated heavy metals from roots to shoots and (ix) tolerance to the toxic effects of the target heavy metals (Sakakibara et al., 2011; Shabani and Sayadi, 2012; Ali et al., 2013; Maric et al., 2013). Phytoremediation comprises several techniques that use plants and associated microbes to remediate contaminated matrices, which are removed through transfer, containment, accumulation or dissipation. The fact that phytoremediation is usually carried out in situ contributes to its cost-effectiveness and may reduce the exposure of the polluted substrate to humans, wildlife and the environment (Pilon-Smits, 2005). Depending on the conditions, the level of clean-up required, the plants used and the contaminants, phytoremediation can be divided into four types: phytoextraction, phytofiltration, phytostabilization and phytovolatilization (Thangavel and Subbhuraam, 2004; Ali et al., 2013).

Phytoextraction is the uptake of contaminants from soil or water by plant roots and their translocation to and accumulation in above-ground biomass (Rafati et al., 2011). Phytofiltration is the removal of pollutants from contaminated surface waters or wastewater (Mukhopadhyay and Maiti, 2010). Removal reach by plants roots (rhizofiltration) or seedlings (blastrofiltration). Seeding roots or plants roots rose in aerated water absorb, precipitate and concentrate heavy metals (Thangavel and Subbhuraam, 2004). Phytostabilization is used to reduce the mobility and bioavailability of pollutants in the environment, thus preventing their migration to groundwater or their entry into the food chain (Erakhrumen, 2007). Phytovolatilization is the uptake of pollutants from soil by plants, their conversion to volatile form and subsequent release into the atmosphere. Among these techniques phytoextraction is the main and most useful technique for removal of heavy metals and metalloids from polluted soils or water (Ali et al., 2013).

The effectiveness of phytoremediation is highly influenced by the bioavailability of metals in soil that depends on several factors: chemical composition, $\mathrm{pH}$, geochemical characteristic of metals, environmental variables and agricultural soil management (Thangavel and Subbhuraam, 2004). Bioavailability can be increased by lowering $\mathrm{pH}$ of soil, using fertilizers, soil microorganisms, root exudates and adding chelating agents (Lone et al., 2008).

\section{Conclusions}

In the commercial agricultural industry, heavy metals are represented as both mineral nutrients and contaminants/ undesirable substances. Although EU has established a comprehensive regulation to control their pollution, their spread at different level does not allow avoiding the presence of heavy metals in the food chain, and in the environment. The control of the animal input could be an effective strategy to reduce human health risks related to the consumption of animal-origin products and the environmental pollution by manure. The diets of livestock can be manipulated in order to reduce the quote of non-absorbed minerals and nutrients that can be present in the manure.

To set up effective strategies against heavy metals the complex interrelationships in rural processes, the widely variability of farming practices, the soil and climatic conditions must be considered. Using the additives with more precision should be suggested in order to avoid spreading the contaminations to the environment. 
Innovative and sustainable approaches have discussed for the heavy metal nutrition ecology to control the environmental pollution from livestock-related activities.

\section{Acknowledgments}

This work was supported by the Ministry of Agriculture Food and Forestry Policies under the Grant MIPAAF 2015.

\section{References}

Alfthan $G$, Eurola $M$, Ekholm $P$, Venäläinen $E R$, Root $T$, Korkalainen $K$, Hartikainen H, Salminen P, Hietaniemi V, Aspila P and Aro A 2015. Effects of nationwide addition of selenium to fertilizers on foods, and animal and human health in Finland: from deficiency to optimal selenium status of the population. Journal of Trace Elements in Medicine and Biology 31, 142-147.

Ali H, Khan E and Anwar Sajad M 2013. Phytoremediation of heavy metals concepts and applications. Chemosphere 91, 869-881.

Aragay G, Pons J and Merkoçi A 2011. Recent trends in macro-, micro-, and nanomaterial-based tools and strategies for heavy-metal detection. Chemical Reviews 111, 3433-3458.

Belon E, Boisson M, Deportes IZ, Eglin TK, Feix I, Bispo AO, Galsomies L, Leblond S and Guellier CR 2012. An inventory of trace elements inputs to French agricultural soils. Science of the Total Environment 439, 87-95.

Bhargava A, Carmona FF, Bhargava M and Srivastava S 2012. Approaches for enhanced phytoextraction of heavy metals. The Journal of Environmental Management 105, 103-120.

Cheli F, Pinotti L, Rossi L and Dell'Orto V 2013. Effect of milling procedures on mycotoxin distribution in wheat fractions: A review. Food Science and Technology 54, 307-314.

Collins J, Prohaska JR and Knutson MD 2010. Metabolic crossroads of iron and cooper. Nutrition reviews 68, 133-177.

Dai SY, Jones B, Lee K-M, Li W, Post L and Herrman TJ 2016. Heavy metal contamination of animal feed in Texas. Journal of Regulatory Science 01, 21-32.

Duruibe JO, Ogwuegbu MOC and Egwurugwu JN 2007. Heavy metal pollution and human biotoxic effects. International Journal of Physical Sciences 2, 112-118.

EFSA 2009. Annual report 2009. Committed to ensuring that Europe's food is safe. EFSA Journal 1-72.

EFSA 2010. Annual report 2010. Committed to ensuring that Europe's food is safe. EFSA Journal 1-68.

EFSA 2015. The European Union summary report on antimicrobial resistance in zoonotic and indicator bacteria from humans, animals and food in 2014. EFSA Journal 15, 4694

Erakhrumen AA 2007. Phytoremediation: an environmentally sound technology for pollution prevention, control and remediation in developing countries. Educational Research and Review Vol 2, 151-156.

Eu I, Yang XE, He ZL and Mahmood Q 2007. Assessing potential dietary toxicity of heavy metals in selected vegetables and food crops. Journal of Zhejiang University SCIENCE B 8, 1-13.

Faridullah F, Pervaiz A, Irshad M, Alam A, Mahmood Q and Ashraf M 2014. Trace elements characterization in fresh and composted livestock manures. The Journal of Hydrology 1, 1-6.

Fink-Gremmels J 2012. Animal feed contamination. Effects on livestock and food safety. Woodhead Publishing Series in Food Science, Technology and Nutrition, Cambridge, UK.

Food Safety Authority of Ireland 2009. Mercury, lead, cadmium, tin and arsenic in food. Toxicology factsheet series $\mathrm{nr}$ 1, 1-13.

García-Vaquero M, Lopez-Alonso M, Benedito JL, Hernandez J, Gutiérrez B and Miranda M 2011. Influence of Cu supplementation on toxic and essential trace element status in intensive reared beef cattle. Food and Chemical Toxicology 49, 3358-3366.

Gerber PJ, Uwizeye UA, Schulte RPO, Opio Cl and Boer de IJM 2014. Nutrient use efficiency: a valuable approach to benchmark the sustainability of nutrient use in global livestock production. Current Opinion in Environmental Sustainability vol. 9-10, 122-130.
Giromini C, Rebucci R, Fusi E, Rossi L, Saccone F and Baldi A 2016. Cytotoxicity, apoptosis, DNA damage and methylation in mammary and kidney epithelial cell lines exposed to ochratoxin. Cell Biology and Toxicology 32, 249-258.

Govind P and Madhuri S 2014. Heavy metals causing toxicity in animals and fishers. Research Journal of Animal, Veterinary and Fishery Sciences Vol. 2, 17-23. Gul S, Naz A, Fareed I, Khan A and Irshad M 2015. Speciation of heavy metals during co-composting of livestock manure. Polish Journal of Chemical Technology 17, 19-23.

Hambidge M 2003. Biomarkers of trace mineral intake and status. The Journal of Nutrition 133, 948-955.

He ZL, Yanga XE and Stoffell PJ 2005. Trace elements in agroecosystems and impacts on the environment. Journal of Trace Elements in Medicine and Biology $19,125-140$.

Ingelmo F, Molina MJ, Desamparados Soriano M, Gallardo A and Lapeña L 2012. Influence of organic matter transformations on the bioavailability of heavy metals in a sludge based compost. The Journal of Environmental Management 95, 104-109.

Jaishankar M, Tseten T, Anbalagan N, Mathew BB and Beeregowda KN 2014. Toxicity, mechanism and health effects of some heavy metals. Interdisciplinary Toxicology. 7, 60-72.

Jakubus M, Dach J and Starmans D 2013. Bioavailability of copper and zinc in pig and cattle slurries. Fresenius Environmental Bulletin 22, 995-1002.

Jarup $L$ 2003. Hazards of heavy metal contamination. British Medical Bulletin 68, 167-182.

Kochare T and Tamir B 2015. Assessment of dairy feeds for heavy metals. The American Scientific Research Journal for Engineering, Technology, and Sciences $11,20-31$.

Lone MI, He Z, Stoffella PJ and Yang X 2008. Phytoremediation of heavy metal polluted soils and water: progresses and perspectives. Journal of Zhejiang University 9, 210-220.

Lopez-Alonso M 2012a. Trace minerals and livestock: not too much not too little. ISRN Veterinary Science 12, 1-18.

Lopez-Alonso M, Garcia-Vaquero M, Benedito JL, Castillo C and Miranda M $2012 \mathrm{~b}$. Trace mineral status and toxic metal accumulation in extensive and intensive pigs in NW Spain. Livestock Science 146, 47-53.

Luo L, Maa Y, Zhang S, Wei D and Zhu Y-G 2009. An inventory of trace element inputs to agricultural soils in China. The Journal of Environmental Management 90, 2524-2530.

Maric M, Antonijevic M and Alagic S 2013. The investigation of the possibility for using some wild and cultivated plants as hyperaccumulators of heavy metals from contaminated soil. Environmental Science and Pollution Research 20, 1181-1188.

Medardus JJ, Molla BZ, Nicol M, Morrow M, Rajala-Schultz P, Kazwala R and Gebreyes WA 2014. In-feed use of heavy metal micronutrients in U.S. swine production systems and its role in persistence of multidrug-resistant Salmonellae. Applied and Environmental Microbiology 80, 2317-2325.

Mohammed Al, Kolo B and Geidam YA 2013. Heavy metals in selected tissues of adult chicken layers (Gallus spp). ARPN Journal of Science and Technology 3, 518-522.

Mukhopadhyay S and Maiti SK 2010. Phytoremediation of metal enriched mine waste: a review. Global Journal of Environmental Research 4, 135-150.

Nicholson FA, Smith SR, Allowayc BJ, Carlton-Smithd C and Chambersa BJ 2003. An inventory of heavy metals inputs to agricultural soils in England and Wales. Science of the Total Environment 311, 205-219.

Nnaji JC, Uzairu A, Gimba C and Kagbu JA 2011. Heavy metal risks in integrated chicken-fish farming. Journal of Applied Sciences 11, 2092-2099.

National Research Council 2000. Nutrient Requirements of Beef Cattle, 7th revised edition. National Academy Press, Washington, DC, USA.

National Research Council 2012. Nutrient Requirements of Beef Cattle, 7th revised edition. National Academy Press, Washington, DC, USA.

Petersen SO, Sommer SG, Béline F, Burton C, Dach J, Dourmad JY, Leip A, Misselbrook T, Nicholson $F$, Poulsen HD, Provolo $G$, Sørensen $P$, Vinnerås $B$, Weiske A, Bernal M-P, Böhm R, Juhász $C$ and Mihelic R 2007. Recycling of livestock manure in a whole-farm perspective. Livestock Science. 112, 180-191. Pilon-Smits E 2005. Phytoremediation. Annual Review of Plant Biology 56, 15-39. Polen T and Voia OS 2015. Copper effect of feed supplementation on growth performance in fattening pigs. Journal of Animal Science 48, 28-30. 
Qiu YW, Lin D, Liu JQ and Zeng EY 2011. Bioaccumulation of trace metals in farmed fish from South China and potential risk assessment. Ecotoxicology and Environmental Safety 74, 284-293.

Radu-Rusu CG, Pop IM, Albu A, Bologa M and Radu-Rusu RM 2013. Transferability of certain heavy metals from hens to table eggs laid within different rearing systems. Lucrări Științifice-Seria Zootehnie 59, 218-222.

Rafati M, Khorasani N, Moattar F, Shirvany A, Moraghebi F and Hosseinzadeh S 2011. Phytoremediation potential of Populus alba and Morus alba for cadmium, chromuim and nickel absorption from polluted soil. International Journal of Environmental Research 5, 961-970.

Raubenheimer D, Simpson SJ and Mayntz D 2009. Nutrition, ecology and nutritional ecology: toward an integrated framework. Functional Ecology. 23, 4-16.

Rehman Ur K, Andleeb S, Mahmood A, Bukhari SM, Naeem MM and Yousaf K 2012. Assessment of heavy metals in different tissues of broilers and domestic layers. Global Veterinaria 9, 32-37.

Rossi L, Dell'Orto V, Vagni S, Sala V, Reggi S and Baldi A 2014a. Protective effect of oral administration of transgenic tobacco seeds against verocytotoxic Escherichia coli strain in piglets. Veterinary Research Communications 38, 39-49.

Rossi L, Di Giancamillo A, Reggi S, Domeneghini C, Baldi A, Sala V, Dell'Orto V, Coddens A, Cox E and Fogher C 2013. Expression of verocytotoxic Escherichia coli antigens in tobacco seeds and evaluation of gut immunity after oral administration in mouse model. Journal of Veterinary Sciences 14, 263-270.

Rossi L, Fusi E, Boglioni M, Giromini C, Rebucci R and Baldi A 2014b. Effect of Zinc oxide and Zinc chloride on human and swine intestinal epithelial cell lines. International Journal of Health. Animal Science and Food Safety 2, 1-7.

Rossi L, Pinotti L, Agazzi A, Dell'Orto V and Baldi A 2014c. Plant bioreactors for the antigenic hook-associated flgK protein expression. Italian Journal of Animal Science 13, 23-29 (b).

Sales J 2013. Effects of pharmacological concentrations of dietary zinc oxide on growth of post-weaning pigs: a meta-analysis. Biological Trace Element Research 152, 343-349.

Sakakibara M, Ohmori Y, Ha NTH, Sano S and Sera K 2011. Phytoremediation of heavy metal contaminated water and sediment by Eleocharis acicularis. Clean: Soil, Air, Water 39, 735-741.

Shabani N and Sayadi MH 2012. Evaluation of heavy metals accumulation by two emergent macrophytes from the polluted soil: an experimental study. Environmentalist. 32, 91-98.
Suleiman N, lbitoye EB, Jimoh AA and Sani ZA 2015. Assessment of heavy metals in chicken feeds available in Sokoto, Nigeria. Sokoto Journal of Veterinary Sciences 13, 17-21.

Suttle NF 2010. Mineral Nutrition of Livestock, 4th Edition. Cabi, Oxfordshire, UK. Tchounwou PB, Yedjou CG, Patlolla AK and Sutton DJ 2012. Heavy metals toxicity and the environment. Experimental Neurology 101, 133-164.

Thangavel P and Subbhuraam C 2004. Phytoextraction: role of hyperaccumulators in metal contaminated soils. Proceedings of the National Academy of Sciences. Part B 70, 109-130.

Theron AJ, Tintinger GR and Anderson R 2012. Harmful interactions of non-essential heavy metals with cells of the innate immune system. Clinical Toxicology 1-10.

Thirulogachandar AME, Rajeswari M and Ramya S 2014. Assessment of heavy metals in Gallus and their impact on human. International Journal of Scientific and Research Publications 4, 1-8.

Van Aken B 2009. Transgenic plants for enhanced phytoremediation of toxic explosives. Current Opinion Biotechnology 20, 231-236.

Walk $C L$, Wilcock $P$ and Magowan E 2015. Evaluation of the effects of pharmacological zinc oxide and phosphorus source on weaned piglet growth performance, plasma minerals and mineral digestibility. Animal 9, 1145-1152.

Wang H, Dong Y, Yang YS, Toor G and Zhang X 2013. Changes in heavy metal contents in animal feeds and manures in an intensive animal production region of China. Journal of Environmental Sciences 25, 2435-2442.

Wuana RA and Okieimen FE 2011. Heavy metals in contaminated soils: a review of sources, chemistry, risks and best available strategies for remediation. ISRN Ecology 2011, 1-20.

Zaninelli M, Rossi L, Costa A, Tangorra FM, Agazzi A and Savoini G 2015. Monitoring of goats' health status by on-line analysis of milk electrical conductivity [Monitoraggio dello stato di salute delle capre attraverso I'analisi on-line della conducibilità elettrica del latte]. Large Animal Review 21, 81-86.

Zhang F, Li Y, Yang M and Li W 2012. Content of heavy metals in animal feeds and manures from farms of different scales in northeast China. International Journal of Environmental Research and Public Health 9, 2658-2668. 